\title{
Estado democrático de direito e administração pós-colonial da diferença: o problema da tutela
}

René Marc da Costa Silva ${ }^{1}$

\section{Resumo}

Com a Constituição de 1988, o Estado Brasileiro foi redefinido como pluriétnico, inserido num contexto plurijurídico. Paradoxalmente, esses avanços não se materializaram numa melhoria da situação social e política dos grupos étnicos minoritários. Ao contrário, esses novos elementos foram ressignificados para manter o sistema hierárquico e desigual da sociedade brasileira. A tutela foi um dos principais mecanismos utilizados neste processo.

Palavras-chave: Direito Internacional. Tutela. Diversidade. Grupos Étnicos. Minorias.

\section{Introdução}

A legislação internacional, desde a Segunda Guerra Mundial, na esteira da força política e da legitimidade que os preceitos dos Direitos Humanos alcançaram na defesa de indivíduos e povos subordinados de todo o mundo, vem se constituindo em instrumento significativo de transformação dos sistemas normativos no interior dos Estados-Nação. O Brasil não ficou alheio a esse processo, haja vista o significativo alinhamento que nosso ordenamento sofreu à luz da forte influência do Direito Internacional, dos muitos tratados, convenções, acordos e protocolos subscritos pelo Estado brasileiro. O impacto desse processo provocou, no caso brasileiro, junto a uma série de outros elementos, a redefinição do desenho constitucional do país e a consequente necessidade de reorientação das relações do Estado

\footnotetext{
${ }^{1}$ Filiação Institucional: Centro Universitário de Brasília - UniCEUB. Formação: Doutor em História pela Universidade de Brasília - UnB, Antropólogo e Professor do Programa de Mestrado e da Graduação do Centro Universitário de Brasília - UniCEUB. E-mail: renecostasilva@gmail.com.
} 
brasileiro com os segmentos sociais minoritários etnicamente marcados. Isso fica patente e se cristaliza na Constituição de 1988.

Esta Carta Magna de fato representou na história jurídica e constitucional brasileira um ponto de clivagem em relação a todo o sistema constitucional anterior, uma vez que reconheceu:

O Estado brasileiro como pluriétnico, e não mais pautado em pretendidas homogeneidades, garantidas ora por uma perspectiva de assimilação, mediante a qual subrepticiamente se instalam entre os diferentes grupos étnicos novos gostos e hábitos, corrompendo-os e levandoos a renegarem a si próprio ao eliminar o específico de sua identidade, ora submetendo-os forçadamente à invisibilidade. $^{2}$

Derivada dessa noção, consolidou-se no país, a partir de 1988, a ideia de que o direito produzido pelo Estado não pode ser considerado como único. Não apenas o pluralismo jurídico ganhou relevância e legitimidade nesse processo, fizeram-se importantes também outras noções de direito oriundas do campo social, das práticas concretas de seus agentes, do cotidiano popular e suas demandas. Permitiram, sobretudo, abrir ataques e críticas ao que se percebia como limitações intrínsecas ao positivismo jurídico, posto que, no âmbito da história constitucional brasileira este, sistematicamente, confundiu os diferentes grupos sociais minoritários no interior da nação com uma ideia totalizante de povo homogeneamente pensado, sem contemplar quaisquer especificidades. Afirmou-se então, durante todo esse período anterior à Constituição de 1988, por parte do Estado, uma ideia de direito unidimensional e plenipotenciária.

Como um dos principais desdobramentos do intenso processo de crítica dessa história nacional de caráter homogeneizante, enfraqueceram-se gradualmente as perspectivas de assimilação dos povos indígenas, como também as ações que visavam sua paulatina integração e redução ao conjunto da sociedade englobante. Deram lugar, por sua vez, a novas ideias pautadas pelo direito e à valorização da diferença, ao reconhecimento da diversidade cultural e étnica, deslocando inevitavelmente as relações entre o Estado e esses povos.

\footnotetext{
${ }^{2}$ PEREIRA, Déborah Duprat. O Estado pluriético. In: LIMA, Antonio Carlos de Souza; BARROSO-HOFFMANN, Maria (Org.). Além da tutela: bases para uma nova política indigenista III. Rio de Janeiro: Contra Capa Livraria, 2002. p. 41.
} 
Tais deslocamentos abriram significativas fendas nas estruturas historicamente hegemônicas de poder, o que permitiu o desenvolvimento de mecanismos de proteção (jurídicos e sociais) efetivos dos modos de ser, viver e existir das diferenças, definidas sociopoliticamente como os outros do poder. Tais instrumentos se tornaram ferramentas importantes, particularmente para grupos sociais minoritários ou marcados etnicamente.

Consubstanciou-se para eles a possibilidade concreta (como no caso dos quilombolas, por exemplo) de se beneficiarem de uma nova modalidade de apropriação (definitiva e coletiva) da terra baseada no artigo 68 do ADCT (Atos das Disposições Constitucionais Transitórias), ou no esvaziamento da tutela como mediadora das relações jurídicas do Estado com as sociedades indígenas.

Contudo, intriga-nos um paradoxo, pelo menos, o que aparenta ser um paradoxo: quanto mais tais redirecionamentos abriram espaço para uma gramática discursiva fortemente pautada pela necessidade de respeito, ações e medidas de promoção da igualdade e dignidade desses grupos sociais, menos se conseguiu viabilizar, todavia, no interior do poder público, uma política étnica definida.

Pelo contrário, como já foi assinalado em outros lugares, ${ }^{3}$ no momento em que se esperava um grande avanço $0^{4}$, no âmbito do Estado, da adoção de uma política étnica ou mesmo de ações governamentais sistemáticas, isso não aconteceu. Ou seja, as ações políticas para tais populações não deixaram de ser desarticuladas, fragmentadas, descontínuas e desorganizadas.

Produziu-se, diferentemente, paralelo a esta 'modernização' do corpo jurídico máximo da nação, uma indisfarçável desorganização nos aparelhos de estado definidos ou incumbidos da tarefa de enfrentarem esta questão. Multiplicam-se, por sua vez, as agências e instituições responsáveis, direta ou indiretamente incumbidas por elaborar e implementar ações, políticas públicas ou projetos orien-

\footnotetext{
${ }^{3}$ BERNO DE ALMEIDA, Alfredo Wagner. Nas bordas da política étnica: os quilombos e as políticas sociais. Boletim Informativo do NUER/UFSC, Florianópolis, v. 2, n. 2, 2005.

${ }^{4}$ Existia, sobretudo a partir dos governos petistas de Lula, uma expectativa difusa no meio social e, nos movimentos sociais particularmente, de que um conjunto de políticas organizadas, sistemáticas, fortemente articuladas com os movimentos sociais tivessem a possibilidade ou capacidade de inverter ou reverter o sentido fortemente colonial presente na mentalidade da sociedade como um todo e nas amadurecidas estruturas de poder institucionais, especificamente.
} 
tados para esses segmentos sociais. Estas, absolutamente, não conseguiram, nem tampouco conseguem ainda hoje, dialogar entre si, articular ações minimamente sistemáticas ou programas com concepções dentro das quais estratégias bem definidas pudessem alavancar tais populações subalternas a condições diferentes das tradicionais relações de poder vigentes no interior da sociedade.

Como pensar esse paradoxo sem cometer alguns equívocos que frequentemente se apresentam como verdadeiras armadilhas ao pensamento. Alguns, por exemplo, imaginaram a sociedade brasileira de final dos anos 1980, madura e pronta para consolidar numa constituição progressista os avanços da redemocratização, impondo-a como derrota definitiva ao imaginário reacionário e às forças sociais conservadoras e seus interesses econômicos e políticos no país. De outro lado, diferentemente, outros sustentam que daquele processo emergiu um Estado de viés modernizador, para o qual se punha mais ou menos clara a exigência de separação entre o público e o privado, a defesa e o respeito a um indivíduo visto como igual perante a lei, caracterizada como universal, em tudo incompatível com uma sociedade percebida como caótica, desorganizada, anti-individualista, essencialmente desigual. Um terceiro conjunto de interpretações, mais sofisticado, enxerga, por sua vez, presente e hegemônico no Estado um núcleo constitutivo de referenciais organizadores, oriundo das sociedades ocidentais, a partir do qual aquele se esforça por disciplinar a sociedade, todavia, por meio de um diálogo - não mais como uma contradição ou antagonismo - que constantemente compõe, acomoda ou concilia tais parâmetros contraditórios ou de sinais divergentes.

Para este último, o traço distintivo da cultura brasileira não seria outro senão esse permanente e eterno esforço conciliador: acomodar impulsos oriundos de um Estado controlado parcialmente por segmentos de elites cujo ideário e horizontes estariam solidamente fincados na grande tradição ocidental europeia, com movimentos de uma sociedade híbrida, marcados por tradições ou matrizes culturais subalternas (africana e indígena) potencialmente desorganizadoras. O pensamento social brasileiro articula-se, basicamente, em torno desses três eixos interpretativos.

Encaminharemos aqui essa reflexão a partir de outra démarche. Compreendemos, outrossim, sociedade e Estado como um todo orgânico em que este último não é mais do que um caixa de passagem de fluxos de energias e tensões nascidas no âmbito da primeira. Não entendemos a sociedade dividida em duas partes distintas, contradi- 
tórias ou antagônicas, lutando entre si. Somos, isto sim, uma sociedade nascida de uma situação colonial originária que articulou diversos elementos de matrizes culturais distintas produtoras e conformadoras de uma tradição singular. Nesse sentido, Estado e sociedade caminham, para nós, em uníssono. O primeiro tão somente institucionaliza antigos mecanismos e dispositivos de poder, promanados de uma estrutura social organizada desde o início como profundamente hierárquica e desigual. Não existem antagonismo nem descompasso fundamental. Trabalham, para a produção e reprodução dessa estrutura, os mais diversos dos seus elementos, inclusive os de matriz ocidental europeia (o direito, por exemplo).

Essa experiência colonial portuguesa promoveu na sua possessão americana um tipo específico de gestão territorial e processos de regionalização, maneiras particulares com as quais determinou estratégias de movimentação, transporte e realocamento de populações subordinadas, além de práticas difusas de agenciamento de forças sociais em aparelhos de Estado ou em suas instituições, orientadas para a disciplinarização, homogeneização e controle do outro do poder. O direito institucionalizado cumpriu nesse processo de normalização e governamentalização um papel decisivo.

Muitos são os exemplos desse exercício colonial e pós-colonial do poder. Tais processos históricos permitem-nos divisar, sobretudo, as formas pelas quais a sociedade brasileira, em geral, e o Estado, em especial, desde o período colonial até bem recentemente, conceberam a diferença etnicamente marcada e se relacionaram com ela: o modo particular do exercício colonial ou pós-colonial do poder, suas estratégias de permanência e reprodução, seus mecanismos, efeitos ou tecnologias - notadamente a tutela, dentre elas. Considerar tais processos ou mecanismos possibilita-nos compreender a forma específica de operar que o poder estrutura com os diversos grupos sociais subordinados no país.

Num determinado sentido, não há descompasso entre uma Constituição avançada e uma sociedade atrasada no Brasil. Não há incongruência entre um Estado de espírito modernizante e uma sociedade, por sua vez, arcaica no país. É a partir de uma cultura ou mentalidade tutelar difusa, presente e atravessando toda a totalidade social que traduzimos os elementos modernizadores ou as inovações jurídicas internacionais, fazendo-as trabalharem, no mais das vezes, para reproduzirem as tradicionais hierarquias e desigualdades políticas, sociais e econômicas recalcitrantemente presentes na sociedade brasileira. 
Este trabalho tem, portanto, como finalidade, produzir uma reflexão sobre os parâmetros que têm orientado e balizado as relações de um Estado caracterizado como pós-colonial com suas agências, empresas públicas ou privadas e comunidades tradicionais ou segmentos sociais subordinados, no âmbito de um contexto essencialmente marcado por esse redimensionamento jurídico nacional e internacional. Com o intuito de tecer, a partir desse emaranhado, algo mais do que uma arquitetura abstrata, coerente, mas vazia de implicações concretas, a tecitura dessas relações nos permitirá compreender de outra forma o processo histórico brasileiro, marcado pelo domínio colonial português, pelo tipo específico de gestão territorial e processos de regionalização que desenvolveu na sua possessão americana, as maneiras com que marcou suas estratégias de movimentação, transporte e realocamento de populações subordinadas, articuladas com práticas difusas de agenciamento de forças sociais em aparelhos de Estado ou em suas instituições, orientadas para a disciplinarização, homogeneização e controle do outro do poder.

A tutela é, no âmbito desse complexo de estratégias, um dos principais dispositivos de controle posto que fundada na transferência de autonomia, iniciativa, direitos, capacidades e prerrogativas do indivíduo para outrem. A tutela, contudo, não se caracteriza nessa reflexão como uma espécie de astúcia do poder do Estado contra a sociedade. Para nós, a tutela é fruto, é resultado prático da maneira como se estruturou o antigo sistema colonial português no Brasil, como nele se organizou, desde o início, a sociedade brasileira, sua ideologia ou cultu$\mathrm{ra}^{5}$. Vivemos, outrossim, numa sociedade pós-colonial como um todo.

5 “Em geral, a 'ideologia' é muito semelhante àquilo que a antropologia americana chama de 'cultura' [...]. Chamamos de ideologia o conjunto de idéias e valores - ou representações - comuns em uma sociedade ou correntes em dado meio social [...], ideologia é [...] um conjunto social de representações [...] elas constituem as categorias de base, os princípios operatórios da 'grade' de consciência, as coordenadas implícitas, em suma, do pensamento comum. [...] A definição de ideologia que adoto repousa [...] em tudo o que é socialmente pensado, acreditado, atuado, a partir da hipótese de que há uma unidade viva disso tudo, escondida sob nossas distinções habituais [...] ela é o veículo espontâneo do nosso pensamento, e nela permanecemos encerrados por tanto tempo que não a tomamos como objeto de nossa reflexão. [...] os elementos de base da ideologia permanecem quase sempre implícitos. As idéias fundamentais são tão evidentes e onipresentes que não tem necessidade de ser expressas: sobre o essencial nada é preciso ser dito, é o que se chama 'a tradição'. DUMONT, Louis. Homo aequalis. São Paulo: Edusc, 2000. p. 19, 29, 32, 35, 41. 
A análise dessas relações, de maneira geral, e da tutela, em particular, permitir-nos-á também colocar em perspectiva a formação de um vasto quadro de funcionários especialistas, seus saberes e práticas acumuladas que se constituíram como representantes, no plano político-administrativo-institucional, de um Estado nacional pós-colonial, agentes diretos de uma cultura política que perpetua na prática, repondo, permanentemente, a desigualdade e que tem como sua ponta de lança o poder tutelar.

Permeará, portanto, o tempo todo na nossa reflexão o modo particular do exercício colonial ou pós-colonial do poder, suas estratégias de permanência e reprodução, seus mecanismos, efeitos ou tecnologias - notadamente dentre eles, a tutela -, objetivando compreender como o Estado e suas agências estruturam, a partir delas, outras tantas formas de dominação com os diversos grupos sociais subordinados no país.

Levantaremos também, de maneira sucinta, a legislação que envolve a questão, atualização que sofreu à luz da forte influência do Direito Internacional, dos muitos convênios e acordos assumidos pelo Estado brasileiro. Assinalaremos o impacto que esse processo operou na significativa redefinição do desenho constitucional do país e na consequente reorientação das relações do Estado brasileiro com os segmentos sociais etnicamente marcados. Apontaremos, todavia, não somente a desorganização que esses movimentos provocaram no aparelho de estado e seu tradicional modelo de administrar as desigualdades em relação às diferenças étnicas no interior da nação, mas também que quanto mais tais redirecionamentos abriram espaço para uma gramática discursiva fortemente pautada pela necessidade de respeito, ações e medidas de promoção da igualdade e dignidade desses grupos sociais, menos se conseguiu viabilizar no interior do poder público uma política étnica definida.

Dedicaremos, todavia, algum espaço no sentido de reunir elementos marcadores da prática concreta do vasto corpo de funcionários receptores, produtores e reprodutores de saberes, rotinas e disciplinas que alcançam o amplo espectro de povos ou comunidades etnicamente marcadas no país, não como instrumentos de libertação ou de autonomia, mas, ao contrário, de subordinação, de controle ou de pacificação. 
E, finalmente, faremos um esforço final no sentido de interpretar todos esses elementos discutidos, no interior de um quadro mais amplo de análise, ao qual já se convencionou chamar de "cultura brasileira". Todavia, nunca a concebendo a partir de um modelo de referência, dissolvente de suas especificidades ou singularidades, mas de outra forma, ela sim como uma completa singularidade.

\section{Direito das minorias no Brasil}

Após a Segunda Guerra Mundial, o Direito Internacional vem progressivamente incorporando preceitos de proteção aos direitos humanos tanto os individuais, como os coletivos. Segundo Ana Valéria Araújo, no final da década de 1970, a agenda internacional começou a incorporar as demandas dos grupos indígenas.

Foram os esforços de grupos indígenas em se organizarem para assegurar a proteção legal ao direito de continuar existindo como comunidades distintas, dotadas de cultura, instituições políticas e territórios próprios, que lhes garantiu a mobilização de diversos programas de organismos internacionais em seu favor. Num apelo à comunidade internacional, os povos indígenas $\mathrm{e}$ algumas organizações de apoio conseguiram ligar esses pleitos a princípios gerais de direitos humanos, como a autodeterminação e o repúdio a qualquer tipo de discriminação. 6

Neste contexto, malgrado o impasse no que concerne ao novo estatuto indígena, os direitos dos povos indígenas vêm se fortalecendo e ganhando maior reconhecimento jurídico internacional, e influenciando a formação de normas de direitos humanos internacionais. Exemplo disso é a Convenção 169 da OIT - Organização Internacional do Trabalho - que trata diretamente sobre Povos Indígenas e Tribais em Países Independentes. Esse tratado internacional, ratificado pelo Brasil em julho de 2002, passou a dar mais atenção aos direitos indígenas, sendo o primeiro instrumento internacional a tratar de temas básicos como o direito dos povos indígenas viverem e desenvolverem-se como povos diferenciados, de acordo com os seus próprios padrões.

\footnotetext{
${ }^{6}$ ARAUJO, Ana. Direito internacional: pleitos e reconhecimento. Disponível em: <http:// www.socioambiental.org/pib/portugues/direito/internac.shtm> Acesso: 01 maio 2008.
} 
A autoidentificação indígena é uma inovação da Convenção, isto é, nenhum Estado ou grupo social pode negar a identidade a um povo indígena que como tal se reconheça. Segundo a OIT - Organização Internacional do Trabalho,

os conceitos básicos, pelos quais se norteia a interpretação das disposições desse instrumento, são a consulta e a participação dos povos interessados e o direito desses de decidir sobre suas próprias prioridades de desenvolvimento na medida em que afete suas vidas, crenças, instituições, valores espirituais e a própria terra que ocupam e utilizam. ${ }^{7}$

Outra novidade da Convenção é a utilização do termo povo, caracterizando segmentos nacionais com identidade e organização próprias, cosmovisão específica e o tipo de relação que possuem com a terra que habitam. Assegura ainda aos povos indígenas igualdade de tratamento e de oportunidades no pleno gozo dos direitos humanos e liberdades fundamentais, sem obstáculo ou discriminação.

Todavia, existem ainda outros instrumentos internacionais que tratam dos direitos humanos. Embora a palavra indígena não apareça diretamente, esses documentos utilizam o conceito de minoria ${ }^{8}$. É preciso salientar que esses tratados internacionais, sancionados pelo Estado Brasileiro, têm força de lei. Neste artigo, não será possível apresentar tais documentos em detalhes e particularidades, no entanto, não nos furtaremos em discorrer sobre cada um deles, ainda que de forma sintética e panorâmica, dada sua importância na constituição do marco legal dentro do qual funciona o Estado brasileiro.

Este é o caso, por exemplo, do Pacto Internacional dos Direitos Econômicos, Sociais e Culturais - PIDESC, adotado pela ONU em 1966, ratificado pelo Brasil em dezembro de 1991 e promulgado em dezembro de 1992, passando, então, a integrar o ordenamento jurídico brasileiro.

\footnotetext{
${ }^{7}$ OIT. Convenção no 169 sobre povos indígenas e tribais em países independentes e Resolução referente à ação da OIT sobre povos indígenas e tribais. Brasília, 2005. p. 11.

${ }^{8}$ Segundo o Procurador Luciano Mariz Maia, o conceito de minoria é genericamente aceito como "grupos distintos dentro da população do Estado, possuindo características étnicas, religiosas ou lingüísticas estáveis, que diferem daquelas do resto da população; em uma posição de não dominância. MAIA, Luciano. Os direitos das minorias étnicas. Disponível em: $<$ http://www.dhnet.org.br/ direitos/militantes/lucianomaia/lmaia_minorias.html>. Acesso em: 05 abr. 2008. Dessa forma os índios se enquadram perfeitamente neste conceito.
} 
O PIDESC estabelece, sob a forma de direitos, as condições sociais, econômicas e culturais para a vida digna. É, todavia, importante assinalar o artigo primeiro que dispõe especificamente sobre o direito à autodeterminação.

No mesmo ano em que foi adotado o PIDESC, foi também aprovado pela ONU o Pacto dos Direitos Civis e Políticos. Esse plano foi ratificado pelo Brasil em janeiro de 1992. O Pacto Internacional de Direitos Civis e Políticos, assim como o PIDESC, faz referência explicita à autonomia dos povos, condição tida como indispensável à vida dessas populações. O jurista João Baptista Herkenhoff ${ }^{9}$ observa que a importância do direito à autodeterminação é condição de subsistência de todos os demais Direitos Humanos.

Por sua vez, a Convenção Americana dos Direitos Humanos foi aprovada pela Organização dos Estados Americanos (OEA) em 1969 e entrou em vigor, no Brasil, em setembro de 1992. Esse documento está fundamentado nos princípios consagrados pela Carta da Organização dos Estados Americanos, pela Declaração Americana dos Direitos e Deveres do Homem e pela Declaração Universal dos Direitos do Homem, e foram reafirmados e desenvolvidos em outros instrumentos internacionais, tanto em âmbito mundial como regional. Seu propósito é consolidar no continente americano, dentro do quadro das instituições democráticas, um regime de liberdade pessoal e de justiça social, fundado no respeito dos direitos essenciais dos seres humanos.

A mesma preocupação se faz presente na Convenção sobre a Eliminação de todas das Formas de Discriminação Racial (CERD), que foi adotada pela ONU em dezembro de 1965, tendo sido ratificada pelo Brasil em março de 1968. A CERD visa à prevenção da discriminação e à proteção de pessoas ou grupos de pessoas particularmente vulneráveis, que merecem um tratamento jurídico especial.

Além dos tratados internacionais, o Brasil também se comprometeu com os demais documentos internacionais, em especial com as declarações de direitos humanos, que não possuem força de lei, mas os Estados se comprometem em segui-las. Também é importante destacar a Declaração dos Povos Indígenas, aprovado no dia 06 de julho de 2006, no âmbito da Organização das Nações Unidas

\footnotetext{
${ }^{9}$ HERKENHOFF, João Baptista. Direitos humanos e direitos dos povos. In: DIREITOS humanos: a construção universal de uma utopia. São Paulo: Santuário, 1997.
} 
(ONU). Segundo a socióloga Azelene Kaingáng - única representante dos indígenas brasileiros presente à sessão do Conselho de Direitos Humanos que aprovou a declaração -, uma das maiores conquistas trazidas pela declaração é o princípio de que qualquer ação em territórios indígenas ou que afete esses povos deve ter o consentimento deles.

Em 2000 foi lançado, também do âmbito da ONU, o Pacto Global cujo objetivo é a mobilização da comunidade empresarial internacional para a promoção (tanto nos locais de trabalho, como em toda a esfera de influência corporativa) dos valores fundamentais nas áreas de direitos humanos, trabalho e meio ambiente.

O Pacto Global procura alertar o setor privado que os direitos humanos são interessantes, desde uma perspectiva de negócios. Assim, os direitos humanos teriam uma dimensão empresarial [...] fundada no reconhecimento de que um bom desempenho neste campo pode ser recompensado comercialmente. ${ }^{10}$

Finalmente, nesse mesmo sentido, encetou-se o compromisso internacional com os Objetivos de Desenvolvimento do Milênio - adotado também em 2000. Esse instrumento internacional vem somar-se ao conjunto de acordos internacionais preocupados com o desenvolvimento sustentável e com os direitos humanos, especialmente das populações vulneráveis.

Mesmo que rápida e panorâmica, a exposição permite chamar a atenção para o fato de que já existe um substancial acordo internacional sobre um conjunto de padrões mínimos favoráveis às reivindicações dos índios e de outras minorias étnicas, que inclusive passaram a integrar manifestações públicas de representantes governamentais e de outras autoridades diante dos mais diversos fóruns internacionais. Nessa perspectiva, assiste-se a um avanço significativo de normas jurídicas - tanto nacionais (aqui especificamente no âmbito constitucional), como internacionais - no que diz respeito ao reconhecimento da cidadania dos povos indígenas e na garantia de seus direitos fundamentais.

${ }^{10}$ HATHAWAY, Gisela. Relação entre o direito internacional ambiental e as instituições financeiras. In: PARREIRA, C.; ALIMONDA, H. (Org.). As instituições financeiras públicas e o meio ambiente no Brasil e na América Latina. Brasília: Flacso/Brasil, 2005. p. 257. 
Nenhum desses avanços, todavia, parece ser suficiente para garantir o respeito efetivo aos direitos conquistados, expostos acima. Isso fica bastante claro quando se observa a "hipertrofia do conceito de áreas de segurança nacional" a partir de um certo revigoramento de uma antiga ideia de estado-nação, que olhava com desconfiança os direitos étnicos como constituindo uma ameaça à sociedade nacional. A ampliação do projeto Calha Norte, as posições 'nacionalistas' face ao aluguel da Base de Lançamento de Alcântara e face à homologação da demarcação da AI Raposa Serra do Sol bem ilustram isto. ${ }^{11}$

A hiperdimensionalização e instrumentalização pela burocracia estatal de um conceito estratégico-militar que na história recente do Brasil remete a um forte conteúdo autoritário, não se mostra de forma nenhuma adequado para pensar ou resolver conflitos étnico-políticos no âmbito de uma sociedade democrática inserida jurídica, política e economicamente no contexto do mundo globalizado num sentido cosmopolita ${ }^{12}$.

Mas não apenas isso; a ambição tutelar, mecanismo que é o núcleo originário de uma variedade de dispositivos de controle e disciplinarização

${ }^{11}$ BERNO DE ALMEIDA, Alfredo Wagner. Nas bordas da política étnica: os quilombos e as políticas sociais. Boletim Informativo do NUER/UFSC, Florianópolis, v. 2, n. 2, p. 18, 2005.

${ }^{12}$ Pensamos aqui cosmopolitismo no sentido dado por Boaventura de Sousa Santos quando o opõe às noções de localismo globalizado que consiste no processo pelo qual determinado fenômeno local é globalizado com sucesso ou a noção de globalismo localizado que, por sua vez, consiste no impacto especifico de práticas e imperativos transnacionais nas condições locais, as quais são, por essa via, desestruturadas e reestruturadas de modo a responder a esses imperativos transnacionais. Cosmopolitismo, como alternativa a esses dois conceitos, trata-se de um conjunto muito vasto e heterogêneo de iniciativas, movimentos e organizações que partilham a luta contra a exclusão e a discriminação sociais e a destruição ambiental produzidas pelos localismos globalizados e pelos globalismos localizados, recorrendo a articulações transnacionais tornadas possíveis pela revolução das tecnologias de informação e comunicação. Nesse sentido, preciso dado por Sousa Santos Cosmopolitismo também difere da idéia de cosmopolitismo no sentido moderno convencional, pois, na modernidade ocidental, cosmopolitismo está associado a idéias de universalismo desenraizado, individualismo, cidadania mundial e negação de fronteiras territoriais e culturais [...], para mim cosmopolitismo é a solidariedade transnacional entre grupos explorados, oprimidos ou excluídos pela globalização hegemônica. Quer se trate de populações hiperlocalizadas (os povos indígenas da Cordilheira dos Andes) ou hipertransnacionalizadas (populações deslocadas pela guerra ou por grandes projetos hidrelétricos, imigrantes ilegais na Europa ou na América do Norte), [...] o cosmopolitismo que defendo éo cosmopolitismo do subalterno e luta contra a subalternização. SANTOS, Boaventura. Reconhecer para libertar: os caminhos do cosmopolitismo multicultural. Rio de Janeiro: Civilização Brasileira, 2003. p. 35-37. 
estatizados (burocrático-administrativos ou não), típico de um Estado póscolonial, avulta também quando se estabelece que:

A Secretaria Executiva do Conselho de Defesa Nacional deverá se manifestar formalmente na decisão oficial de reconhecimento das comunidades quilombolas, consoante os Arts. 8 e 11 do Decreto n. 4887. De acordo com o Art. 8 deverá "opinar" sobre o relatório técnico relativo aos trabalhos de identificação e de delimitação, produzidos pelo INCRA, e pelo Art. 11 tomará as medidas cabíveis caso as terras ocupadas pelas comunidades remanescentes de quilombos estejam sobrepostas às áreas de segurança nacional. Por essa via, administradores civis e militares, com atividades referidas a tal competência e que já vêm desenvolvendo um "saber prático" sobre as comunidades remanescentes de quilombos, têm condições de possibilidade para consolidar suas convicções eivadas de preconceitos e de intuições em tudo etnocêntricas. 13

\section{Dispositivos de poderes coloniais e pós-coloniais e a constituição de 1988}

No tocante à questão indígena, a partir da Constituição de 1988, como já foi enfatizado, criou-se no âmbito do ordenamento jurídico brasileiro a necessidade de profundas reorientações. Com o reconhecimento e respeito às organizações sociais e culturais dos povos indígenas, ocorreram deslocamentos incontornáveis na maneira como o Estado lidava com a população indígena: a FUNAI deixou de ter a competência exclusiva para entrar em juízo na defesa de direitos e interesses dos índios. As questões indígenas passam a ser de competência da Justiça Federal e a responsabilidade de defender judicialmente os direitos indígenas incluiu-se dentre as atribuições do Ministério Público da União.

Tais deslocamentos deixaram explícito o reconhecimento de que o Brasil é uma nação formada por uma imensa pluralidade social, étnica e cultural, um verdadeiro Estado

\footnotetext{
${ }^{13}$ BERNO DE ALMEIDA, Alfredo Wagner. Nas bordas da política étnica: os quilombos e as políticas sociais. Boletim Informativo do NUER/UFSC, Florianópolis, v. 2, n. 2, p. 19, 2005
} 
pluriétnico e também plurijurídico ${ }^{14}$; atravessado por diferentes influências historicamente determinadas e, consequentemente, tributário de variados processos externos e internos de empréstimos, imposição e difusão.

No campo jurídico, esses empréstimos, trocas e imposições continuam acontecendo. Intensificaram-se mesmo, sobretudo, pela importância crescente do Direito Internacional, dos ordenamentos e regimes jurídicos supranacionais, da transnacionalização do direito estatal e da atuação e participação concreta de instituições multilaterais, ONGs transnacionais, doadores internacionais e outros, mas, sobretudo e, principalmente, pela nova correlação de forças impostas pela luta jurídico-política incisiva e determinada das diversas comunidades tradicionais. Isso, consequentemente, não apenas modificou a natureza das tradicionais funções reguladoras e protetoras do direito, como também alterou as condições de sua legitimação. Estas, para se fazerem presentes no atual contexto, não podem prescindir mais da intervenção direta dos atores internacionais na arena jurídica nacional ${ }^{15}$, nem

\footnotetext{
${ }^{14}$ Randeria lembra, com muita propriedade acerca disso que, “a idéia de pluralismo jurídico, central para a antropologia jurídica dos anos 60 e 70, questiona as assunções básicas da teoria política e da jurisprudência liberais, especialmente no que diz respeito à congruência entre o território, o Estado e o direito. Ao trazermos para o primeiro plano a coexistência de uma pluralidade de ordenamentos jurídicos no seio de uma unidade política única, particularmente dos direitos consuetudinários das comunidades e dos direitos religiosos a par com o direito da metrópole e com o direito criado especificamente nas e para as colônias nas sociedades (pós)-coloniais, o pluralismo jurídico questiona a centralidade do direito elaborado pelo Estado e sua exigência de exclusividade no ordenamento normativo da vida social. RANDERIA, Shalini. Pluralismo jurídico, soberania fraturada e direitos de cidadania diferenciais: instituições internacionais, movimentos sociais e Estado pós-colonial na Índia. In: SANTOS, Boaventura (Org.). Reconhecer para libertar: os caminhos do cosmopolitismo multicultural. Rio de Janeiro: Civilização Brasileira, 2003 .p. 467.

15 A transnacionalização e o pluralismo jurídico, no sentido da multiplicidade de atores, arenas, métodos e formas de produção do direito, também estão alterando a própria natureza e a noção de direito como um corpo coerente e unitário de conhecimento e prática de tomada de decisões baseada em princípios. À medida que o governo é substituído por uma pluralidade de regimes de governo supra e infra-estatais, com atores públicos e privados, há um direito descentralizado e microscópico que coexiste, de uma forma mais ou menos incômoda, com o direito monumental que anteriormente era monopólio dos Estados. O domínio do direito está sendo expandido no processo de inclusão de convenções, tratados, acordos bilaterais e multilaterais, bem como de protocolos com efeito jurídico, embora esses não possam ser entendidos como direito, no sentido estrito que possuam uma base legislativa [...]. A criação do direito torna-se cada vez mais um processo contínuo, de origem tanto administrativa quanto legislativa, sendo as regras, regulamentos e prescrições produzidas a partir de uma diversidade de fontes locais com fronteiras inconstantes" RANDERIA, Shalini. Pluralismo jurídico, soberania fraturada e direitos de cidadania diferenciais: instituições internacionais, movimentos sociais e Estado pós-colonial na Índia. In: SANTOS, Boaventura (Org.). Reconhecer para libertar: os caminhos do cosmopolitismo multicultural. Rio de Janeiro: Civilização Brasileira, 2003 p. 467-468.
} 
da ativa inserção das comunidades tradicionais locais e suas demandas nos foros jurídicopolíticos internacionais.

Exatamente por isso, ainda há muito a fazer. Apesar de todos os avanços e inovações jurídicas internacionais materializadas e consubstanciadas na Constituição de 1988, no caso específico referente à questão indígena, ainda não há no Brasil leis ordinárias que regulamentem as normas constitucionais. Segundo Ana Valéria Araújo e Sérgio Leitão o advento da nova Constituição traz a urgente necessidade de reformular o Estatuto do Índio (Lei 6.001/1973) que tem seus fundamentos centrados na noção de tutela e assimilação dos povos indígenas à comunhão nacional. ${ }^{16}$

Era preciso regulamentar temas presentes no texto constitucional que reclamavam detalhamento em leis específicas para serem plenamente executados, como a proteção aos recursos hídricos existentes em terras indígenas e o estabelecimento de salvaguardas para os índios no caso de realização de atividades mineradoras em seus territórios. ${ }^{17}$

Atualmente existem dois projetos de lei no Congresso Federal sobre o Estatuto das Sociedades Indígenas, ambos em consonância com a Constituição Federal. Alguns especialistas afirmam que a promulgação do novo Estatuto será fundamental para se superar a herança da tutela e reafirmar os índios enquanto sujeitos diretos dos seus próprios direitos. ${ }^{18}$

O Estatuto do Índio de 1973 e grande parte das políticas indigenistas baseadas nessa lei são completamente anacrônicas e contraditórias, se vistas pela ótica da Constituição e do direito moderno. A Constituição de 1988 tem suas bases assentadas no respeito à diferença e no reconhecimento da identidade indígena. Já o Estatuto do Índio constrói seus parâmetros a partir da necessidade da tutela,

${ }^{16}$ ARAÚJO, Ana; LEITÃO, Sergio. Direitos indígenas: avanços e impasses pós-1988. In: LIMA, Antonio; HOFFMANN, Maria (Org.). Além da tutela: bases para uma política indigenista III. Rio de Janeiro: LACED, 2002.

${ }^{17}$ ARAÚJO, Ana; LEITÃO, Sergio. Direitos indígenas: avanços e impasses pós-1988. In: LIMA, Antonio; HOFFMANN, Maria (Org.). Além da tutela: bases para uma política indigenista III. Rio de Janeiro: LACED, 2002.

${ }^{18}$ ISA - INSTITUTO SOCIOAMBIENTAL. Caracterização socioambiental das terras indígenas no Brasil. Disponível em: <http://www.socioambiental.org/pib/portugues/ quonqua/indicadores/detalhes_ti.html?id_arp=3799>. Acesso: 11 set. 2008. 
"pacificação" e assimilação dos índios à comunhão nacional. Em função disso, a questão da tutela ocupa um lugar central no debate e no processo de aprovação do novo Estatuto das Sociedades Indígenas. As discussões mais acirradas dão-se sobre a capacidade civil dos indígenas e sobre as alterações do atual sistema de tutela.

O texto do substutivo aprovado em 1994, assim como o da proposta alternativa apresentada em 2000 , propõe o fim da tutela e da conceituação dos índios como relativamente incapazes, sem descurar da necessidade de um tratamento diferenciado em razão de suas peculiaridades culturais, estabelecendo mecanismos de proteção. ${ }^{19}$

Não parece ser tarefa fácil para os autores sociais da cena indigenista brasileira conviver com duas legislações tão destoantes:

No que tange aos índios, as políticas públicas do Estado brasileiro padecem hoje, em sua implementação, de certo grau de esquizofrenia, fruto da convivência de um texto constitucional extremamente avançado com um Estatuto do Índio arcaico e fundado em conceitos totalmente superados, que mesmo assim dita as regras do dia-a-dia da aplicação dessas políticas. Por exemplo, quando a procuradoria da Funai se manifesta oficialmente contrária à criação de associações indígenas sem o aval do órgão, contestando a validade dos atos por elas praticados em função de sua condição de relativamente incapazes. Ao mesmo tempo, não vê qualquer problema no fato de eles assumirem o cargo de administrador de unidades regionais do órgão e entender que a tutela os isenta de responsabilidade em casos de eventuais irregularidades. ${ }^{20}$

Contudo, para compreender adequadamente esse descompasso ou aparente contradição, é fundamental enfatizar a persistência do caráter pós-colonial do Estado brasileiro. Um Estado de formação recente, construído sobre estruturas frágeis; vinculado em posição subalterna ao sistema internacional, profundamente dependente de recursos externos e subordinados às orientações das agências internacionais, e que, sobretudo, ainda não colonizou completamente o imaginário das suas populações.

\footnotetext{
${ }^{19}$ ARAÚJO, Ana; LEITÃO, Sergio. Direitos indígenas: avanços e impasses pós-1988. In: LIMA, Antonio; HOFFMANN, Maria (Org.). Além da tutela: bases para uma política indigenista III. Rio de Janeiro: LACED, 2002. p. 25.

${ }^{20}$ ARAÚJO, Ana; LEITÃO, Sergio. Direitos indígenas: avanços e impasses pós-1988. In: LIMA, Antonio; HOFFMANN, Maria (Org.). Além da tutela: bases para uma política indigenista III. Rio de Janeiro: LACED, 2002. p. 28.
} 
No campo jurídico, essas condições implicaram e determinam ainda, por seu turno que,

uma vez que os Estados (pós)-coloniais nunca possuíram monopólio absoluto sobre a produção do direito, as especificidades de suas trajetórias contemporâneas de globalização econômica e jurídica apenas podem ser analisadas contra o pano de fundo das continuidades históricas, frequentemente apresentadas como processos de recolonização. ${ }^{21}$

É o caso, por exemplo, da permanência da mão forte da tutela expressa nas discussões relativas à extração das riquezas naturais que asseguram a reprodução física e cultural das comunidades indígenas. A promotora Juliana Santilli ${ }^{22}$ salienta que foi por reconhecer a dependência das comunidades indígenas em relação ao seu habitat natural, que a Constituição impôs ao Poder Público a obrigação de defender e preservar não só as terras habitadas pelos índios, como também as utilizadas para suas atividades produtivas, as imprescindíveis à preservação dos recursos ambientais necessários a seu bem-estar e as necessárias à sua reprodução física e cultural, segundo seus usos, costumes e tradições. Entretanto, se, para a Constituição, a posse e o usufruto exclusivo de suas riquezas são dos índios, o texto constitucional não se esquece de ressaltar, contudo, que a propriedade das terras indígenas continua sendo da União.

Nesse mesmo sentido, a Constituição também estabelece que o aproveitamento dos recursos hídricos, incluídos os potenciais energéticos, a pesquisa e a lavra das riquezas minerais, só podem ser efetivados com a autorização do Congresso Nacional, ainda que, ouvidas as comunidades afetadas, ficando-lhes assegurada a participação nos resultados da lavra. Mesmo com todas essas salvaguardas e exceções, apesar de necessária, ainda não existe lei ordinária (ou vontade política) que fixe as condições específicas para exploração mineral e de recursos hídricos nas Terras Indígenas.

\footnotetext{
${ }^{21}$ RANDERIA, Shalini. Pluralismo jurídico, soberania fraturada e direitos de cidadania diferenciais: instituições internacionais, movimentos sociais e Estado pós-colonial na Índia. In: SANTOS, Boaventura (Org.). Reconhecer para libertar: os caminhos do cosmopolitismo multicultural. Rio de Janeiro: Civilização Brasileira, 2003. p. 468.

22 SANTILLI. Juliana. Atividades econômicas em terras indígenas. Brasília: ISA, 2000. Disponível em: <www.socioambiental.org/pib/portugues/direito/ativecon. shtm>. Acesso em: 17 mar. 2008.
} 


\section{Administrando a diferença - por uma compreensão outra do Estado pós- colonial e seu funcionamento}

Para compreender a questão envolvida nessa problemática é essencial pensar, fundamentalmente, como viemos acima sugerindo, a formação histórica do Estadonação brasileiro, suas agências, as empresas nacionais ou transnacionais e seus interesses vinculados ao país, os organismos políticos internacionais como fonte jurídica e os povos e comunidades locais integrantes da comunidade nacional, vale dizer; o caráter pós-colonial da inserção específica do Brasil no cenário internacional globalizado. Acreditamos que pensar sobre o complexo jogo de forças entre esses atores permite avançar a reflexão sobre as dificuldades, obstáculos e resistências à lenta transformação das leis esparsas e pontuais, medidas e ações desarticuladas relativas às minorias no interior do Estado-nação e sua transformação em verdadeiras políticas étnicas de Estado, como efetivos instrumentos de emancipação.

A história da formação dos Estados na América Latina tem como prévio desdobramento, a descoberta das Américas e das rotas marítimas para as Índias, marco inicial do colonialismo mercantilista moderno. Quando aqui chegaram, os portugueses não encontraram terras desocupadas, mas territórios densamente povoados por sociedades contra as quais logo se moveu guerra e uma destruição de proporções até então pouco vistas. A história dessas guerras é também, como não poderia deixar de ser, a história de uma aguerrida resistência que se organizou de diversas formas, dentre elas a fuga e o aquilombamento em lugares ermos e de difícil acesso.

A formação do Estado Nacional brasileiro em meados do século XIX, levado a cabo por uma elite de descendente de europeus, descompromissada com a vontade e os interesses dos diversos povos subordinados que aqui habitavam ou que para aqui foram trazidos, pouco modificou o estatuto exógeno, não integrado das comunidades indígenas ou dos povos e etnias que compunham a rica diversidade do país - vistos, quase sempre, como primitivos, estrangeiros ou hostis.

Consoante a isso, o Estado-Nação brasileiro, fortemente articulado a interesses das classes hegemônicas nacionais ou estrangeiros, ensaiando seus primeiros passos no que viria a se tornar política de captação/atração de mão-de-obra imigrante europeia, já por meados do século XIX, avançava desproporcionalmente sua fronteira agrícola, ampliando a procura por novas terras e riquezas no interior 
do país. A expansão dessa fronteira novamente alcançou povos indígenas e comunidades tradicionais isolados, considerados, invariavelmente, como signos do persistente atraso e entrave ao desenvolvimento do país. A subordinação total dessas populações e dos espaços por elas ocupados completou-se com a sua completa pacificação.

Enfim, tal percurso que abrange conjunturas históricas que vão do final do século XIX, passando pela primeira República, mas que não se esgotam nem com o fim do SPI (Serviço de Proteção ao Índio) nem mesmo com o esvaziamento da FUNAI (Fundação Nacional do Índio), a partir dos anos 1990, revelam, isto sim, ao contrário, a permanência de fato de um tipo específico de gestão territorial e processos de regionalização com sua necessária articulação a discursos e saberes determinados, em tempo, associados ás práticas difusas de agenciamento de forças sociais em aparelhos de Estado, apontando, em última análise, para a disciplinarização, para a homogeinização e para o controle da dinâmica social. Parece-nos ser esta a melhor expressão do significado da aproximação, do controle e da subordinação sobre populações tradicionais e sobre terras indígenas realizadas pelo Estado e suas agências.

Tal como está em Foucault, ser-nos-ia útil então matizar aqui nossa abordagem do particular processo de construção histórica do poder do Estado brasileiro, especificamente no ponto em que este autor se refere ao poder em termos de combate, de guerra e de confronto.

A célebre inversão que Foucault faz de Clausewitz (a política é a guerra realizada por outros meios), permite pensar o fim das lutas de conquistas e a "pacificação" da diferença étnica no Brasil23 ${ }^{23}$ pelo descendente de europeu. Tal se finaliza ou se materializa na consolidação de um Estado controlado hegemonicamente por uma elite de descendentes europeus, numa administração pública centralizada e forte e em suas agências especializadas no outro, na alteridade do poder (tais como o SPI, a FUNAI e

23 "O poder político, nessa hipótese, teria como função reinserir perpetuamente essa relação de força, mediante uma espécie de guerra silenciosa, e de reinseri-la nas instituições, nas desigualdades econômicas, na linguagem, até nos corpos de uns e de outros. Seria, pois, o primeiro sentido a dar a esta inversão do aforismo de Clausewitz: a política é a guerra continuada por outros meios; isto é, a política é a sanção e a recondução do desequilíbrio das forças manifestado na guerra". FOUCAULT, Michel. Em defesa da sociedade. São Paulo: M. Fontes, 1999. p. 23. 
outras), responsáveis pela produção de rotinas, disciplinas e controles sobre as comunidades etnicamente marcadas, no sentido de subordiná-las e reproduzir a dominação transfigurada na ordem do poder estatal.

A governamentalização de poderes sociais que deriva desse processo implica, por parte do Estado, na estrita administração das populações, sua disciplinarização e a consequente redefinição dos indivíduos e dos grupos sociais no espaço e no tempo, permitindo um controle social tentacular.

Ao mesmo tempo que isso e, por outro lado, trata-se também de entender o poder não exatamente prisioneiro da imobilidade de suas estruturas e instituições, mas:

[...] uma mecânica de poder que se expande por toda a sociedade, assumindo as formas mais regionais e concretas, investindo em instituições, tomando corpo em técnicas de dominação. Poder este que intervêm materialmente, atingindo a realidade mais concreta dos indivíduos - o seu corpo - e que se situa ao nível do próprio corpo social, e não acima dele, penetrando na vida cotidiana e por isso podendo ser caracterizado como micro-poder ou sub-poder [...], a consideração do poder em suas extremidades, a atenção a suas formas locais, a seus lineamentos tem como correlato a investigação dos procedimentos técnicos de poder que realizam um controle detalhado, minucioso do corpo gestos, atitudes, comportamentos, hábitos, discursos. ${ }^{24}$

O Estado seria, diferentemente do que propõe a teoria clássica, precisamente, como na leitura particular que Deleuze faz de Foucault; um processo permanente de estatização de poderes ou forças sociais, apropriadas, reelaboradas, ressignificadas a partir de saberes e discursos produtores de um regime específico de verdades e de

\footnotetext{
${ }^{24}$ MACHADO, Roberto. Por uma genealogia do poder. In: FOUCAULT, Michel. Microfísica do poder. Rio de Janeiro: Graal, 1988. p. 12.
} 
seus efeitos de poder $^{25}$, voltados para o controle da mobilidade espacial, da produção simbólica da legitimidade e da conquista ${ }^{26}$ de variados grupos sociais definidos como o outro do Estado, pelos setores hegemônicos que o dirigem. O Estado, então, nessa perspectiva, deveria ser compreendido muito mais como organizador de linhas de tensão e fluxos de velocidades mensuráveis, vale dizer, vórtice de agenciamentos ${ }^{27}$, sem

25 "O que é o Poder? A definição de Foucault parece bem simples: o poder é uma relação de forças, ou melhor, toda relação de forças é uma 'relação de poder'. Compreendamos primeiramente que o poder não é uma forma, por exemplo, a forma-Estado [...]; em segundo lugar, a força não está nunca no singular, ela tem como característica essencial estar em relação com outras forças, de forma que toda força já é relação, isto é, é poder [...], a força não tem outro objeto além de outras forças, não tem outro ser além da relação. [...] É por essa razão que as grandes teses de Foucault sobre o poder, como vimos anteriormente, desenvolvem-se em três rubricas: o poder não é essencialmente repressivo (já que 'incita, suscita e produz'); ele se exerce antes de se possuir (já que só se possui sob uma forma determinável - a classe - e determinada - Estado); passa pelos dominados tanto quanto pelos dominantes (já que passa por todas as forças em relação) [...] sobretudo se considerarmos que a força afetada não deixa de ter uma capacidade de resistência. [...] O poder, ao contrário, é diagramático: mobiliza matérias e funções não-estratificadas, e procede através de uma segmentaridade bastante flexível. Com efeito ele não passa por formas, mas por pontos, pontos singulares que marcam, a cada vez, a aplicação de uma força, a ação ou reação de uma força em relação às outras, isto é, um afeto como 'estado de poder sempre local e instável.' [...] é a instabilidade das relações de poder que define um meio estratégico ou não-estratificado. [...] O que há é uma multiplicidade de integrações locais, parciais, cada uma em afinidade com tais relações, tais pontos singulares. Os fatores de integração, agentes de estratificação, constituem instituições: o Estado - mas também a Família, a Religião, a Produção, o Mercado, a própria Arte, a Moral... As instituições não são fontes ou essências, e não têm essência ou interioridade. São práticas, mecanismos operatórios que não explicam o poder, já que supõem as relações e se contentam em 'fixá-las' sob uma função reprodutora e não produtora. Não existe Estado, apenas uma estatização. DELEUZE, Gilles. Foucault. São Paulo: Brasiliense, 1988. p. 78, 79, 81, 83.

${ }^{26}$ É a presença do outro, como categoria e realidade - habitante dos espaços a serem assenhoreados por um movimento de expansão de um eu/nós - o elemento lógico a detonar um universo de possibilidades relacionais, nos planos social e simbólico, melhor caracterizável por uma modalidade de guerra, e como fundamento de certas formas de poder que a sucedem, passível de ser elaborado e intitulado de conquista. SOUZA LIMA, Antônio Carlos. Um grande cerco de paz: poder tutelar, indianidade e formação do Estado no Brasil. Rio de Janeiro: Petrópolis, 1995. p. 46.

${ }^{27}$ Um agenciamento maquínico é direcionado para os estratos que fazem dele, sem dúvida, uma espécie de organismo, ou bem uma totalidade significante, ou bem uma determinação atribuível a um sujeito, mas ele não é menos direcionado para um corpo sem órgãos, que não pára de desfazer o organismo, de fazer passar e circular partículas a-significantes, intensidades puras, e não pára de atribuir-se os sujeitos aos quais não deixa senão um nome como rastro de uma intensidade. Considerado por Deleuze como um feixe de agenciamentos, ao Estado perguntar-se-á antes, "com o que ele funciona, em conexão como o que ele faz ou não passar intensidades, em que multiplicidades ele se introduz e metamorfoseia a sua, com que corpos sem órgãos ele faz convergir o seu. DELEUZE, Gilles; GUATTARI, Gilles. Mil platôs: capitalismo e esquizofrenia. Rio de Janeiro: 34, 1995. p. 12. 
origem determinada, sem tronco, sem núcleo; mas, outrossim, circulantes, dinâmicos, indeterminados, mutantes.

\section{Pluralismo jurídico, estado pluriétnico e pós-colonialismo}

O pluralismo jurídico introduzido no Brasil a partir da Constituição de 1988, para a qual o direito produzido pelo Estado não é o único, as críticas ao positivismo jurídico que desde sempre subordinou e esvaziou a realidade pluriétnica nacional dissolvida no interior da noção unitária e homogênea de "povo", o combate à receita clássica do evolucionismo e seu ideário de assimilação dos índios, tribos e diferenças correlatas pela sociedade dominante, certamente propiciaram o desenvolvimento de um novo tipo de relação jurídica entre o Estado e as "minorias", pautado pelo discurso do respeito à diversidade étnica e cultural.

Tais rupturas e conquistas, todavia, não foram capazes de propiciar ou dotar o Estado brasileiro de:

uma política étnica e nem tampouco [...] ações governamentais sistemáticas capazes de reconhecer prontamente os fatores situacionais que influenciam uma consciência étnica. Mesmo levando em conta que o poder é efetivamente expresso sob uma forma jurídica ou que a linguagem do poder é o direito, há enormes dificuldades de implementação de disposições legais desta ordem, sobretudo em sociedades autoritárias e de fundamentos coloniais e escravistas, como no caso brasileiro. ${ }^{28}$

A constituição de 1988, malgrado seus incontestáveis avanços, não pode ser compreendida simplesmente como reflexo de uma vontade modernizante e igualitária (no sentido liberal), ou mesmo antitradicional e anti-hierárquica da sociedade brasileira. Ao contrário disso, a Assembléia Nacional Constituinte, a despeito dos enormes avanços materializados na Constituição de 1988, foi, ela mesma, palco de incontáveis lobbies, articulações de interesses corporativos de diferentes setores da sociedade e da manutenção de variados tipos de privilégios socialmente consolidados.

${ }^{28}$ BERNO DE ALMEIDA, Alfredo Wagner. Nas bordas da política étnica: os quilombos e as políticas sociais. Boletim Informativo do NUER/UFSC, Florianópolis, v. 2, n. 2, p. 15-16, 2005. 
Ao contrário de uma "revolução liberal", o que se viu na constituinte a partir da Constituição de 1988 foi, sob a rubrica das inovações jurídicas acima assinaladas, sob a égide dos novos deveres e responsabilidades assumidos pelo Estado, a transferência de poderes sociais prontamente governamentalizados. A Constituição de 1988 não ensejou ondas de iniciativas por parte da sociedade civil, ligadas a práticas emancipatórias, demandadoras de autonomia e potencialmente criadoras de poder social. Ao contrário, consolidou a crença difusa no meio social nos poderes quase demiúrgicos do Estado patrimonial e estamental como fonte doadora de poder.

A transferência desses poderes sociais para o Estado, por um lado, mas também o trânsito livre na sociedade de uma mentalidade colonial patriarcal, hierárquica e que enxerga a desigualdade como natural, materializou-se particularmente nas diversas dimensões do exercício livre da tutela, sustentada amplamente em uma maneira específica de diversos segmentos sociais verem a si mesmos e aos outros, entenderem de maneira peculiar o funcionamento da própria sociedade e do Estado e de se organizarem no interior da totalidade social.

Para além da maneira específica de relacionar as minorias étnicas (e outras), a tutela ${ }^{29}$ é, sobretudo, a maneira como a sociedade se vê, constrói relações,

${ }^{29}$ Tutela aqui pode ser entendida de maneira ampliada de modo a alcançar variados "processos de regionalização e gestão territorial, e a produção de saberes a eles articulados; as práticas de aparelhos de governo destinados, dentre outras coisas, ao controle da mobilidade espacial de segmentos da população brasileira (índios, menores, migrantes, favelados). [...] Supõe e implica a atribuição da capacidade relativa a estas populações e a necessária tutela jurídica por parte do Estado. Implantá-lo demandou criar e expandir, em efetivo numérico e em termos de espaço abrangido, segmentos administrativos também específicos, dispostos sob forma de uma malha governamental concebida como de espectro nacional. Sua criação, por parte do governo federal, demandou a articulação de redes sociais efetivamente em controle de partes do território brasileiro [...] entretecendo-as como parte de um único aparelho administrativo com funções de governo. SOUZA LIMA, Antônio Carlos. Sobre gestar e gerir a desigualdade: pontos de investigação e diálogo. In: SOUZA LIMA, Antônio Carlos (Org.). Gestar e gerir: estudos para uma antropologia da administração pública no Brasil. Rio de Janeiro: Relume Dumará, 2002. p. 11, 14. 
organiza-se $^{30}$ e se institucionaliza ${ }^{31}$. Tanto essa relação quanto essa especial forma de organização do social, ambas, são historicamente determinadas, e, sobretudo, reafirmadoras da produção estratégica de uma lacuna, a saber: a concepção de uma política étnica que seja capaz de reorientar a própria ideia de nação brasileira e, a partir disso, ser capaz também de estabelecer parâmetros e critérios para conceber ações públicas específicas que efetivamente deem respostas satisfatórias às demandas de emancipação e autonomia a esses grupos sociais.

O conceito amplo de tutela com o qual trabalhamos aqui põe a nu o forte caráter pós-colonial do Estado e da sociedade brasileira. A tutela propriamente relativa às sociedades indígenas é, por sua vez, bastante similar ás incidentes sobre diversos outros grupos sociais minoritários. Tutela aqui significa, portanto, "um modo específico de estatização de certos poderes incidentes sobre o espaço, através do controle e da alocação diferencial e hierarquizada de populações, para as quais se criam estatutos diferenciados e discricionários nos planos jurídico e/ou administrativo" 32

\footnotetext{
${ }^{30}$ A propósito disso, Castoriadis assinala que e impossível captar um 'conteúdo' da vida social que seria primário e se 'daria' uma expressão nas instituições independente delas; esse 'conteúdo' (diferentemente do que como momento parcial e abstrato, separado depois), só é definível em uma estrutura, e esta comporta sempre a instituição. As 'relações sociais reais' de que se trata são sempre instituídas, não porque tenham uma vestimenta jurídica (ela podem muito bem não tê-las em certos casos), mas porque foram estabelecidas como maneiras de fazer universais, simbolizadas e sancionadas. [...] A relação patrão-escravo, servo-senhor, proletário-capitalista, assalariadosburocracia já é uma instituição e não pode aparecer como relação social sem se institucionalizar imediatamente. Como exemplo disso, Castoriadis assevera que, até mesmo "[...] as relações de produção articuladas na escala social [...] significam ipso facto uma rede, ao mesmo tempo real e simbólica que sanciona ela própria - por conseguinte, uma instituição" CASTORIADIS, Cornelius. A instituição imaginária da sociedade. Rio de Janeiro: Paz e Terra, 1982. p.151.

${ }^{31}$ Trabalhando precisamente com essa orientação, mas tendo John Searle como referencial teórico, Lima Lopes mostra que: "Quando o comportamento dos sujeitos exige ações cooperativas (desde fazer uma ponte, até 'constituir' uma família), é necessário compartilhar estados intencionais (crenças, desejos, intenções). E, para além dos objetos, pode-se criar uma instituição, isto é, algo que só existe por meio de regras [...]. A instituição incorpora uma 'intencionalidade compartilhada', objetiva e constitui-se por regras que valem. Para 'valer' dependem de que haja intenções coletivas sobre ela”. LIMA LOPES, José Reinaldo. Iluminismo e jusnaturalismo no ideário dos juristas da primeira metade do século XIX. In: JANCSÓ, István. (Org.). Brasil: formação do Estado e da Nação. São Paulo: Hucitec, 2003. p. 197.

${ }^{32}$ SOUZA LIMA, Antônio Carlos. Sobre gestar e gerir a desigualdade: pontos de investigação e diálogo. In: SOUZA LIMA, Antônio Carlos (Org.). Gestar e gerir: estudos para uma antropologia da administração pública no Brasil. Rio de Janeiro: Relume Dumará, 2002. p. 14.
} 
Característica modelar das sociedades a que se convencionou chamar póscoloniais, a administração da desigualdade, exemplar na figura da tutela e o rico e diversificado gradil de suas manifestações, são índices do prodigioso esforço de parte de setores tradicionalmente dominantes do país, respaldados por uma mentalidade colonial ou pós-colonial difusa, em manter os quadros de produção e reprodução de sua hegemonia, mesmo em novos contextos históricos. Nesse sentido, o poder tutelar aparece como uma possibilidade de entender e abordar o próprio processo histórico de formação da sociedade brasileira e do Estado ${ }^{33}$.

Weber, em passagem inspirada, enfatiza que "para a vida cotidiana, dominação é primariamente administração". ${ }^{4}$ As palavras gestar e administrar revelam em sua matriz comum um mesmo sentido. "Gestar - formar e sustentar (um filho) no próprio ventre" 35 e "Gerir - exercer gerência sobre: administrar, digerir, gerenciar"36 tem a mesma matriz etimológica e permite-nos compreender uma mesma e única operação de controle, disciplinarização e dominação, relativos aos agenciamentos necessários ao exercício do poder.

O que se quer neste trabalho, sobretudo, é assinalar a especificidade do processo histórico, do qual resultou a formação particular da sociedade e de um moderno Estado no Brasil, oriundos e desdobrados diretamente de um contexto colonial, e como reproduziram na contemporaneidade, no sentido de manter as formas gerais tutelares de dominação estabelecidas pelo antigo sistema colonial português que os caracterizou no passado, aquelas mesmas hierarquias de valores, visões de mundo e modos de estabelecer relações com a alteridade, quer elas

\footnotetext{
${ }^{33}$ Correspondendo ao delineamento de um formato sócio-político, à definição básica de seus limites internacionais e expansão sobre o espaço geográfico por estes incluídos [...]. A este modo de relacionamento e governamentalização de poderes, concebido para coincidir sobre uma única nação, denomina-se aqui poder tutela. SOUZA LIMA, Antônio Carlos. Um grande cerco de paz: poder tutelar, indianidade e formação do Estado no Brasil. Rio de Janeiro: Petrópolis, 1995. p. 39.

${ }^{34}$ WEBER, Max. Economia y sociedad. México: Fondo de Cultura Económica, 1983. p. 175.

${ }^{35}$ HOUAISS, A.; VILLAR, M. Dicionário Houaiss da língua portuguesa. Rio de Janeiro: Objetiva, 2001. p. 1449.

${ }^{36}$ HOUAISS, A.; VILLAR, M. Dicionário Houaiss da língua portuguesa. Rio de Janeiro: Objetiva, 2001. p. 1447.
} 
fossem mulheres, índios, negros e outras tantas categorias que, naquele contexto de então, encontravam suas posições e formas específicas de subordinação ${ }^{37}$.

É precisamente no sentido, portanto, de produção e reprodução de um Estado (ou de uma disposição específica de relações de força e seus efeitos de poder) definido como pós-colonial, que se pode compreender a ideia de dominação caracterizadora da noção de administração em Weber: administrar aqui é como que gerenciar as diferenças, governamentalizar alteridades, digerindo e englobando o outro, gestando e dissolvendo-o na totalidade do ventre social, percebido como homogêneo ${ }^{38}$.

Inserido num contexto propriamente pós-colonial, pluralismo jurídico acaba por não ser outra coisa que mera ficção. Organizada a sociedade em torno de um lugar para onde convergem e são produzidas não apenas as principais iniciativas percebidas como legítimas, mas também as demandas principais da coletividade social, o Estado parece-nos um lócus concentrador, mobilizador e hierarquizador de sentidos para onde são atraídos e gravitam como satélites; toda autonomia possível.

\section{A FUNAI e a tutela: obstáculos à construção de uma política étnica}

Toda essa transformação jurídica presente na Constituição de 1988, extensamente discutida anteriormente e que aponta para o fim da tutela e da ideia de

\footnotetext{
${ }^{37}$ Pois administrar, num certo nível, é também pôr em movimento dispositivos capazes de engendrar e de repetir - e fazer repetir - esquemas de percepção e ação da vida diária ao ponto de torná-los automáticos e inquestionáveis. SOUZA LIMA, Antônio Carlos. Um grande cerco de paz: poder tutelar, indianidade e formação do Estado no Brasil. Rio de Janeiro: Petrópolis, 1995. p. 18.

${ }^{38}$ Que sociedade, que Estado e que nação surgiriam, pois, da invasão e do confronto entre conquistador e conquistados? Conseqüentemente, quais as continuidades e distanciamentos dados a cada novo povo indígena pacificado? O que é o Índio, termo apropriado para ser matéria de incidência de um conjunto de práticas e representações governamentalizadas? Perguntas muito abrangentes e informes [...], contudo é possível recolocá-las ao se reconhecer que toda conquista envolve subseqüente administração do butim, processo capaz de produzir homogeneidades inexistentes antes de sua intervenção: de terras indivisas, ou sujeitas a outros padrões de delimitação, criam-se territórios, produz-se uma população capaz de se reconhecer como uma comunidade (enquanto objeto de controle racional por aparelhos de poder) onde antes só existiam povos dispersos, histórica, linguística e culturalmente distintos. SOUZA LIMA, Antônio Carlos. Um grande cerco de paz: poder tutelar, indianidade e formação do Estado no Brasil. Rio de Janeiro: Petrópolis, 1995. p. 67.
} 
incapacidade relativa dos índios, malgrados todos os seus inquestionáveis avanços, ressalta, outrossim, a particularidade de um conjunto de relações de forças específicas, que ressignifica, reinterpreta, traduz os avanços conquistados e materializados num aparato jurídico e político que afirma direitos coletivos (sem quaisquer regulamentações infraconstitucionais), mas que mantém inalterado como pedra de toque a estrutura legal pretérita no que concerne à referência fundamental e nuclear ao indivíduo e à propriedade privada individual, à mentalidade tutelar, às hierarquizações sociais e aos privilégios. Tal ressignificação permite afirmar, por um lado, a autonomia e a responsabilidade civil desses povos, ao mesmo tempo em que mantém intactos os tradicionais instrumentos, mecanismos e dispositivos tutelares de administração, controle e disciplina - numa palavra, o modelo póscolonial de governamentalização dessa e de outras populações subordinadas.

Essas dificuldades também têm se apresentado com particular intensidade, principalmente, no campo das reivindicações e das lutas quilombolas pela titulação definitiva das suas terras ancestrais. Da mesma forma aqui, encontramos um conjunto de agências do governo, vinculadas, em áreas diferentes de atuação e interesse, a questões, muitas vezes em contradição umas com as outras, na medida em que também, por seu turno, representam elas próprias forças sociais vivas da sociedade e seus interesses políticos, econômicos e estratégicos.

Tais forças sociais, que se mobilizam no âmbito dos diversos segmentos da sociedade - reunindo forças e capital político, capazes de agenciar interesses específicos no jogo de poder no interior dos aparelhos governamentais, (usando de seus instrumentos, técnicas e práticas tradicionais), e no andamento de seus processos político-jurídico/administrativo/burocrático de encaminhamento e tomada de decisões - não se furtam em lançar mão, no mais das vezes, do vasto aparato jurídico tradicional tutelar de encaminhamento das demandas sociais.

O Ministério do Desenvolvimento Agrário - MDA e agências a ele vinculadas, como é o caso, por exemplo, do INCRA, vêm sustentando que a melhor forma de dar encaminhamento jurídico mais efetivo e célere ás demandas jurídicas por titulação definitiva das terras, que tem sido o objetivo mais obstinadamente perseguido pelas comunidades tradicionais negras espalhadas pelo país, seria acionar os mecanismos de ação agrária já disponíveis, isto é, transformar substancialmente uma questão de políti- 
ca étnica e cultural em simples ações burocrático/administrativas de caráter fundiário. O deslocamento da luta dos negros pela terra, dessa esfera política e étnica para outra fundiária, encontra forte oposição de agências como a Fundação Cultural Palmares e a Secretaria Especial de Políticas para Promoção da Igualdade Racial - SEPPIR.

Percebem elas o perigo iminente de dissolução dos fatores étnicos e políticos envolvidos na luta em meras questões agrárias. Tais instrumentos de ação fundiária, como é o caso do usucapião e outros, só fariam conferir às terras reivindicadas o status de terras parcelares, individuais, sem o caráter jurídico de propriedade comum, indivisível, fundamentada em elementos étnicos, políticos e culturais como ocupação histórica e resistência ancestrais, religião, territorialidade, usos e costumes. De quilombolas, comunidades marcadas étnica e culturalmente por uma história e ancestralidade específica, transformar-se-iam, de um salto, em uma massa de trabalhadores rurais, lutando no âmbito inespecífico da reforma agrária.

Mais do que isso, tal deslocamento obrigaria o enquadramento da pluralidade de territorialidades negras nos quadros estreitos dos tipos clássicos de cadastramento da terra usada pelo INCRA, tais como, imóvel rural e estabelecimento ${ }^{39}$. Ora, a inade-

${ }^{39}$ O Cadastro de Imóveis Rurais do INCRA adota, desde 1966, a seguinte definição operacional: 'Imóvel rural, para os fins do cadastro, é o prédio rústico, de área contínua, formado de uma ou mais parcelas de terra, pertencentes a um mesmo dono, que seja ou possa ser utilizados em exploração agrícola, pecuária, extrativa vegetal ou agroindustrial, independente de sua localização na zona rural ou urbana do município. 'As restrições são as seguintes: os imóveis localizados na zona rural e cuja área total seja inferior a $5.000 \mathrm{~m} 2$ não são abrangidos por essa classificação de 'imóvel rural', e aqueles localizados na zona urbana somente serão cadastrados quando tiverem área total igual ou superior a 2 ha., bem como produção comercializada [...]. A noção de "estabelecimento" vem sendo utilizada desde que, em 1950, o Recenseamento Geral envolveu, dentre outros, os censos demográfico e agrícola. Em conformidade com esses censos, 'considerou-se como estabelecimento agropecuário todo terreno de área contínua, independente do tamanho ou situação (urbana ou rural), formado de uma ou mais parcelas, subordinado a um único produto, onde se processasse uma exploração agropecuária, ou seja: o cultivo do solo com culturas permanentes ou temporárias, inclusive hortaliças e flores; a criação, recriação ou engorda de animais de grande e médio porte; a criação de pequenos animais; a silvicultura ou o reflorestamento; a extração de produtos vegetais. Excluíram-se da investigação os quintais de residências e hortas domésticas. "E ainda: 'as áreas confinantes sob a mesma administração, ocupadas segundo diferentes condições legais (próprias, arrendadas, ocupadas gratuitamente), foram consideradas um único estabelecimento. Apud BERNO DE ALMEIDA, Alfredo Wagner. Nas bordas da política étnica: os quilombos e as políticas sociais. Boletim Informativo do NUER/UFSC, Florianópolis, v. 2, n. 2, 2005. 
quação é evidente. Terras de Preto, Mocambos, Terras de Santo, Comunidades Negras, são denominações que aludem a processos particulares de territorialização historicamente determinados que ostentam, de forma incontornável, a dimensão étnica como parte indissociável dela. São terras que se caracterizam por serem propriedades coletivas, de uso comum e variedade de culturas, indivisíveis e indisponíveis para venda.

Contudo, a tentativa desse deslocamento não deve ser entendida apenas como uma simples inadequação da máquina administrativa estatal ou meramente debitada na conta das contradições internas da engrenagem que estrutura a complexa relação entre as agências do Estado. $\mathrm{O}$ mercado de terras no Brasil, hipervalorizado por um mercado internacional globalizado, ávido por adquirir enorme volume de comodities, tais como soja e carne bovina, estimula um duplo movimento: se por um lado, a pressão sobre as áreas cultiváveis eleva o preço das terras mais ricas, por outro, a necessidade de novas e mais amplas áreas de pastagem para o gado, expande a fronteira rural do agrobusines. O impacto disso sobre as terras indígenas, quilombolas e reservas naturais ou protegidas é evidente.

Com relação aos quilombolas particularmente, Berno de Almeida assinala que o grande perigo que ameaça ao aquecido mercado de terras é substancialmente este:

a propriedade definitiva idealmente tornaria todos 'iguais' nas relações de mercado, com os quilombolas, emancipados de qualquer tutela, se expressando através de uma via comunitária de acesso a terra. $\mathrm{O}$ fato da propriedade não ser necessariamente individualizada e aparecer sempre condicionada ao controle de associações comunitárias tornaas, entretanto, um obstáculo às tentativas de transações comerciais e praticamente as imobiliza enquanto mercadoria. As terras das comunidades quilombolas cumprem sua função social precípua, quando o grupo étnico, manifesto pelo poder da organização comunitária, gerencia os recursos no sentido de sua reprodução física e cultural, recusando-se a dispô-los às transações comerciais. ${ }^{40}$

No que concerne aos povos indígenas, a FUNAI se apresenta como um lugar inteiramente despreparado para dar respostas satisfatórias, isto é, emancipatórias às demandas dos povos indígenas. A ausência de uma política étnica para o país obriga

${ }^{40}$ BERNO DE ALMEIDA, Alfredo Wagner. Nas bordas da política étnica: os quilombos e as políticas sociais. Boletim Informativo do NUER/UFSC, Florianópolis, v. 2, n. 2, p. 23, 2005 
“as iniciativas do órgão tutor sempre se (configurarem) como uma resposta a uma situação de emergência" "41, uma rotina de se estar sempre apagando o incêndio do dia. Em tal contexto, a tônica do órgão é sempre a tomada de decisões empíricas, uma completa ausência de hierarquizações de necessidades, programas que se constituem em meros ordenamentos formais de fins burocráticos, completamente divorciados das necessidades dos povos indígenas, girando, frequentemente, ao sabor de práticas utilitárias, pragmáticas ou assistencialistas, aberto a um indigenismo carente de análises técnicas especializadas. Num quadro como esse, o que ressalta é a completa inocuidade de se estabelecer planos e prioridades. As preocupações com identificação, delimitação e demarcação das terras indígenas são recentes e apresentam outras fragilidades ${ }^{42}$. Enfim, um modelo autoritário de 'planejamento, ainda fortemente articulado a uma ideologia desenvolvimentista, burocratizada e despolitizada. ${ }^{43}$

A FUNAI ainda é, em grande medida, um aparato estatizado em que se estruturam mecanismos e dispositivos de poderes tutelares para onde convergem relações de forças sociais que impõe a produção e reprodução contínua de relações de poderes caracterizados como de molde colonial ou pós-colonial, maneiras de ver e de se relacionar com o outro do poder, vale dizer especificamente suas minorias étnicas, de forma a mantê-los indefinidamente subordinados.

Tais mecanismos ou dispositivos coloniais e pós-coloniais de poder, incorporados à rotina das agências, instituições ou aparelhos estatizados e

\footnotetext{
${ }^{41}$ OLIVEIRA, João Pacheco; BERNO DE ALMEIDA, Alfredo Wagner. Demarcação e reafirmação étnica: um ensaio sobre a FUNAI. In: OLIVEIRA, João Pacheco (Org.). Indigenismo e territorialização: poderes, rotinas e saberes coloniais no Brasil contemporâneo. Rio de Janeiro: Contracapa, 1998. p. 70.

${ }^{42}$ Considerações nas quais não entraremos, posto que estenderia demasiadamente esta reflexão. Todavia, ela está perfeitamente delineada em OLIVEIRA, João Pacheco (Org.). Indigenismo e territorialização: podres, rotinas e saberes coloniais no Brasil contemporâneo. Rio de Janeiro: Contracapa, 1988.

${ }^{43}$ OLIVEIRA, João Pacheco; BERNO DE ALMEIDA, Alfredo Wagner. Demarcação e reafirmação étnica: um ensaio sobre a FUNAI. In: OLIVEIRA, João Pacheco (Org.). Indigenismo e territorialização: poderes, rotinas e saberes coloniais no Brasil contemporâneo. Rio de Janeiro: Contracapa, 1998. p. 72.
} 
que permitem a ressignificação, a adaptação ou acomodação ${ }^{44}$ das inovações ou novidades jurídicas trazidas dos ordenamentos jurídicos internacionais e incorporadas ao direito pátrio, ainda que tenham possibilitado a reprodução do modelo hegemônico de dominação, acabaram por incapacitar,de uma vez por todas, o tradicional aparato burocrático-administrativo do Estado especializado no seu outro de se adequar às novas e progressistas demandas dos movimentos sociais inscritas no ordenamento jurídico pós 1988. Ao ressignificá-las, desarmou-se nelas seu limitado potencial transformador, libertador. Mas não somente isso; tornou mais visível também e por outro lado, a completa incongruência dos instrumentos técnicos e jurídicos tradicionais de controle e disciplinarização da diferença, historicamente utilizados por essas instituições, como manifestamente anacrônicos frente aos novos sentidos, novos objetivos, parâmetros e variadas outras formas de intervenções definidas e exigidas pelos grupos sociais subordinados e pela constituição para essas instituições.

${ }^{44}$ É de fundamental importância assinalar a persistência desse traço, estruturante da sociedade brasileira, caracterizador de toda a sua evolução histórica e ainda fortemente presente na atualidade, e que teve no direito, ao longo de todo esse percurso, o seu principal instrumento. Wheling enfatiza que a principal "característica do direito ibérico foi seu caráter estamental" e que a história mesmo do absolutismo ibérico e suas possessões pode "ser estudada como a história da tensão entre a centralização, com ou sem sua plena constituição burocrática, e a reação particularista dos senhores territoriais, do clero regular e das estruturas corporativas - estes últimos, nem sempre acordes entre si, uma das razões de sua fraqueza ante o rei -, o mesmo ocorre com o direito. Tal perspectiva do absolutismo não deve induzir, entretanto, a uma excessiva antinomia moderno (o Estado real) versus arcaico (a sociedade estamentada e corporativa). A própria monarquia absoluta dos séculos XVI e XVII era ainda estamental e corporativa, concedendo privilégios e gerando direitos que se contrapunham ou poderiam contrapor-se aos esforços centralizadores. Mesmo no século XVIII, no apogeu da atuação centralizadora dos burocratas absolutistas de Portugal, França, Espanha ou Toscana, ainda existiam setores do Estado e mecanismos institucionais que continuavam a emitir privilégios e isenções, gerando assim novos direitos particulares." Continuando, contudo, Wheling não se furta em mostrar que a antiguidade histórica e o caráter estruturante para a sociedade brasileira do mecanismo de ressignificação, adaptação ou acomodação que estamos a assinalar, implicou num particular impacto sobre o direito. Para o autor, "fontes múltiplas e divergentes não são a única consequência da sociedade estamentalizada para o direito. Também a desigualdade perante a lei, de acordo com a condição social do autor e do réu, era traço significativo, em especial do direito penal. WEHLING, Arno; WEHLING, Maria José. Direito e justiça no Brasil colonial. Rio de Janeiro: Renovar, 2004. p. 15-16. 
No caso específico dos povos indígenas, as propostas de substituição da tutela têm encontrado em segmentos organizados dentro da Fundação Nacional do Índio - FUNAI, enormes resistências ${ }^{45}$.

Está claro que não se pode ver o Estado como um bloco coeso e homogêneo, com ações perfeitamente articuladas entre suas diversas instâncias, supostamente defendendo interesses coetâneos. Todavia, as novidades jurídicas trazidas pela Constituição de 1988, não só acabaram por acirrar antigas contradições no interior das próprias agências do Estado, como o já mencionado caso da FUNAI, como também promoveram novas e complexas contradições entre as agências e no interior de cada uma delas.

É assim, nos limites desse quadro que faz sentido e se torna inteligível, por sua vez, pensar também o complexo processo que envolve as articulações entre as demandas do mundo globalizado e as necessidades e prioridades das comunidades locais. É no conjunto dessas coordenadas que ora alargam-se estrategicamente os parâmetros jurídicos nacionais e internacionais que balizam as relações entre os diversos agentes políticos ou burocráticos com as comunidades tradicionais, ora forçam o Estado a redefinir seus dispositivos de poder no enfrentamento de situações específicas na relação de suas agências com tais comunidades ou na administração das relações dessas com empresas nacionais ou transnacionais.

É no âmbito dessa moldura de uma paisagem tutelar ampla, que podemos colocar também em perspectiva a formação de um vasto quadro de funcionários especialistas, seus saberes e práticas acumuladas, que se constituíram como representantes no plano político-administrativo-institucional de uma cultura geral tutelar e de um Estado nacional pós-colonial, gentes diretos de um modo de fazer e entender política que perpetua na prática, repondo permanentemente, a desigualdade e que tem como sua ponta de lança a tutela como ferramenta.

\footnotetext{
${ }^{45}$ Segundo Araújo e Leitão, "tais setores da FUNAI, sob o argumento de ameaça de extinção do órgão e consequente abandono da proteção dos povos indígenas por parte do Estado, acabam mobilizando índios que, em razão de seus vínculos orgânicos e de sua dependência em relação à estrutura de clientelismo patrocinada com os recursos do próprio orçamento da FUNAI, constituem-se em tropa de choque permanentemente utilizada para agredir quem queira debater o tema com seriedade". ARAÚJO, Ana; LEITÃO, Sergio. Direitos indígenas: avanços e impasses pós-1988. In: LIMA, Antonio; HOFFMANN, Maria (Org.). Além da tutela: bases para uma política indigenista III. Rio de Janeiro: LACED, 2002. p. 26.
} 
No interior desse quadro, não existe, portanto, um descompasso entre as inovações jurídico-políticas internacionais trazidas e incorporadas pela Constituição de 1988 e essas agências - nascidas em meio ao atraso, à Lei de Segurança Nacional, o período autoritário etc.

Tais agências e seu vasto corpo de funcionários, de outra maneira, são hábeis em traduzir, ressignificar e canalizar a novidade desses elementos constitucionais para os fins últimos de produzir, manter e reproduzir a estrutura colonial hierárquica de poder, seus valores e horizontes. Essas agências ou instituições, não são obsoletas como é comum pensar; funcionam muito bem. A ausência de ações sistemáticas, coordenadas e integradas à ineficiência de procedimentos antiquados, além da total inexistência de planejamento, são, diferentemente, a ponta de lança de estratégias pós-coloniais de um Estado que dá concretude a uma consciência social geral tutelar.

Em síntese, nosso entendimento, portanto, sobre esse (aparente) paradoxo ou descompasso, é a percepção de que é, outrossim, a sociedade brasileira como um todo que é tutelar e de que não existe propriamente um "Estado" de caráter moderno ou modernizante, representando e afirmando, em separado, a hegemonia de uma elite pautada ou formada a partir de elementos individualistas, fundada na separação entre público e privado, afirmando uma crença igualitária etc., que seriam, por sua vez, vistos como traços isolados, constitutivos de uma tradição ocidental particular, idealmente desconectada (ainda que para efeito analítico) da totalidade social.

\section{The democratic state of law and post-colonial adminstration of difference - the tutelage problem}

\section{Abstract}

Since the Constitution of 1988, the Brazilian State was redefined as pluriethnic, within a plurijuridical context. Paradoxically, these advances did not materialize as an improvement of the social and political situation of the minority ethnical groups. On the contrary, these new elements were re-signified to keep the hierarchic and unequal system of the Brazilian society. Tutelage was one of the main mechanisms used in such process.

Keywords: International Law. Tutelage. Diversity. Ethnic Groups. Minorities. 


\section{Referências}

ALMEIDA, Eduardo. Autonomia indígena em laboratório. In: POVOS indígenas no Brasil: 2001 - 2005. São Paulo: ISA, 2006.

ANDRELLO, Geraldo. Taurepang: história. São Paulo, 2004. Disponível em: $<$ http://www.socioambiental.org/pib/epi/pib/epi/taurepang/hist.shtm.> Acesso em: 10 mar. 2009

ARAUJO, Ana. Direito internacional: pleitos e reconhecimento. Disponível em: $<$ http:// www.socioambiental.org/pib/portugues/direito/internac.shtm> Acesso: 01 maio 2008.

ARAÚJO, Ana; LEITÃO, Sergio. Direitos indígenas: avanços e impasses pós-1988. In: LIMA, Antonio; HOFFMANN, Maria (Org.). Além da tutela: bases para uma política indigenista III. Rio de Janeiro: LACED, 2002.

BERNO DE ALMEIDA, Alfredo Wagner. Nas bordas da política étnica: os quilombos e as políticas sociais. Boletim Informativo do NUER/UFSC, Florianópolis, v. 2, n. 2, 2005.

BRAND, Antonio. Mudanças e continuísmos na política indigenista pós-1988. In: LIMA, Antonio; HOFFMANN, Maria (Org.). Estado e povos indígenas: bases para uma política indigenista II. Rio de Janeiro: LACED, 2002.

BRASIL. Constituição (1988). Constituição da República Federativa do Brasil. Brasília: Senado Federal, 1988.

CASTORIADIS, Cornelius. A instituição imaginária da sociedade. Rio de Janeiro: Paz e Terra, 1982.

. Sujeito e verdade: no mundo social-histórico. Rio de Janeiro: Civilização Brasileira, 2007.

CUNHA, M. Carneiro da Os direitos dos índios, ensaios e documentos. São Paulo: Brasiliense, 1987.

DELEUZE, Gilles. Foucault. São Paulo: Brasiliense, 1988. . Nietzsche e a filosofia. Rio de Janeiro: Rio, 1976.

DELEUZE, Gilles; GUATTARI, Gilles. Mil platôs: capitalismo e esquizofrenia. Rio de Janeiro: 34, 1995.

DERRIDA, Jacques. A farmácia de Platão. São Paulo: Iluminuras, 2005. 
. Da hospitalidade. São Paulo: Esculta, 2003.

. Margens da filosofia. São Paulo: Paysannes; Papirus, 1991.

. O monolinguismo do outro: ou a prótese de origem. Porto: Campos das Letras, 1996.

DUMONT, Louis. Homo aequalis. São Paulo: Edusc, 2000.

DUPRAT, Marés. As novas questões jurídicas nas relações dos Estados nacionais com os índios. In LIMA, Antonio; HOFFMANN, Maria (Org.). Além da tutela: bases para uma política indigenista III. Rio de Janeiro: LACED, 2002.

FOUCAULT, Michel. Em defesa da sociedade. São Paulo: M. Fontes, 1999.

HATHAWAY, Gisela. Relação entre o direito internacional ambiental e as instituições financeiras. In: PARREIRA, C.; ALIMONDA, H. (Org.). As instituições financeiras públicas e o meio ambiente no Brasil e na América Latina. Brasília: Flacso/Brasil, 2005.

HERKENHOFF, João Baptista. Direitos humanos e direitos dos povos. In: DIREITOS humanos: a construção universal de uma utopia. São Paulo: Santuário, 1997.

HOUAISS, A.; VILLAR, M. Dicionário Houaiss da língua portuguesa. Rio de Janeiro: Objetiva, 2001.

IBGE. Base de dados sobre os municípios brasileiros. Disponível em: <http://www. ibge.gov.br/cidadesat/default.php>. Acesso: 10 set. 2008.

INSTITUTO WARA. Declaração dos povos indígenas, aprovado no dia 06 de julho de 2006, no âmbito da Organização das Nações Unidas. Disponível em: <http://www. institutowara.org.br>. Acesso: 02 jan. 2008.

ISA - INSTITUTO SOCIOAMBIENTAL. Caracterização socioambiental das terras indígenas no Brasil. Disponível em: <http://www.socioambiental. org/pib/portugues/ quonqua/indicadores/detalhes_ti.html?id_arp=3799>. Acesso: 11 set. 2008.

LIMA, Antonio; HOFFMANN, Maria. Além de tutela: aspectos de uma nova regulação dos direitos indígenas no Brasil. In: LIMA, Antonio; HOFFMANN, Maria (Org.). Além da tutela: bases para uma política indigenista III. Rio de Janeiro: LACED, 2002. 
LIMA LOPES, José Reinaldo. Iluminismo e jusnaturalismo no ideário dos juristas da primeira metade do século XIX. In: JANCSÓ, István. (Org.). Brasil: formação do Estado e da Nação. São Paulo: Hucitec, 2003.

MACHADO, Roberto. Por uma genealogia do poder. In: FOUCAULT, Michel. Microfísica do poder. Rio de Janeiro: Graal, 1988.

MAGALHÃES, Edvard. Legislação indigenista brasileira. Brasília: FUNAI; Dedoc, 2002.

MAIA, Luciano. Os direitos das minorias étnicas. Disponível em: <http://www.dhnet.org. br/direitos/militantes/lucianomaia/lmaia_minorias.html>. Acesso em: 05 abr. 2008.

OIT. Convenção $n^{\circ} 169$ sobre povos indígenas e tribais em países independentes e Resolução referente à ação da OIT sobre povos indígenas e tribais. Brasília, 2005.

OLIVEIRA, João Pacheco. Cidadania e globalização: povos indígenas e agências multilaterais. In: LIMA, Antonio; HOFFMANN, Maria (Org.). Além da tutela: bases para uma política indigenista III. Rio de Janeiro: LACED, 2002.

OLIVEIRA, João Pacheco; BERNO DE ALMEIDA, Alfredo Wagner. Demarcação e reafirmação étnica: um ensaio sobre a FUNAI. In: OLIVEIRA, João Pacheco (Org.). Indigenismo e territorialização: poderes, rotinas e saberes coloniais no Brasil contemporâneo. Rio de Janeiro: Contracapa, 1998.

OLIVEIRA, João Pacheco; IGLESIAS, Marcelo. As demarcações participativas e o fortalecimento das organizações indígenas. In: LIMA, Antonio; HOFFMANN, Maria (Orgs.). Estado e povos indígenas: bases para uma política indigenista II. Rio de Janeiro: LACED, 2002.

OLIVEIRA, João Pacheco (Org.). Indigenismo e territorialização: podres, rotinas e saberes coloniais no Brasil contemporâneo. Rio de Janeiro: Contracapa, 1988.

PEREIRA, Déborah Duprat. O Estado pluriético. In: LIMA, Antonio Carlos de Souza; BARROSO-HOFFMANN, Maria (Org.). Além da tutela: bases para uma nova política indigenista III. Rio de Janeiro: Contra Capa Livraria, 2002.

PNUD-BRASIL. Objetivos de desenvolvimento do milênio. Disponível em: <http:// www.pnud.org.br/odm/index.php?lay=odmi\&id=odmi $>$ Acesso: 02 jan. 2008.

POUTIGNAT, Philippe; STRIFF-FENART, Jocelyne. Teorias da etnicidade. São Paulo: UNESP, 1998. 
RAMOS, Adriana. Os índios e o novo Congresso Nacional. In: LIMA, Antonio; HOFFMANN, Maria (Org.). Além da tutela: bases para uma política indigenista III. Rio de Janeiro: LACED, 2002.

RANDERIA, Shalini. Pluralismo jurídico, soberania fraturada e direitos de cidadania diferenciais: instituições internacionais, movimentos sociais e Estado pós-colonial na Índia. In: SANTOS, Boaventura (Org.). Reconhecer para libertar: os caminhos do cosmopolitismo multicultural. Rio de Janeiro: Civilização Brasileira, 2003.

RIOS, Aurélio. Terras indígenas no Brasil: definição, reconhecimento e novas formas de aquisição. In: LIMA, Antonio; HOFFMANN, Maria (Org.). Além da tutela: bases para uma política indigenista III. Rio de Janeiro: LACED, 2002.

SANTILLI, Juliana. Atividades econômicas em terras indígenas. Brasília: ISA, 2000. Disponível em: <www.socioambiental.org/pib/portugues/direito/ ativecon.shtm>. Acesso em: 17 mar. 2008.

SANTILLI, Paulo. Macuxi: história do contato. Brasília, 2004. Disponível em: <http:// www.socioambiental.org/pib/epi/macuxi/hist.shtm>. Acesso em: 17 mar. 2008.

SANTOS, Boaventura. Reconhecer para libertar: os caminhos do cosmopolitismo multicultural. Rio de Janeiro: Civilização Brasileira, 2003.

SANTOS, Raimundo. Roraima: a construção de identidades políticas indígenas e não- indígenas no final do século XX. Tese (Doutorado)-UFRJ. Rio de Janeiro, 2003.

SEDH. Convenção sobre a eliminação de todas as formas de discriminação racial. Disponível em: <http://www.mj.gov.br/sedh/ct/legis_intern/conv_int_eliminacao_ disc_racial.htm>. Acesso: 02 jan. 2008

. Pacto internacional dos direitos econômicos, sociais e culturais. Disponível em: <http://www.mj.gov.br/sedh/ct/legis_intern/pacto_dir_ economicos.htm.>. Acesso: 02 jan. 2008.

. Convenção americana dos direitos humanos. Disponível em: <http://www. mj.gov.br/sedh/ct/legis_intern/conv_americana_dir_humanos.htm>. Acesso: 02 jan. 2008.

. Pacto dos direitos civis e políticos. Disponível em: <http://www.mj. gov.br/

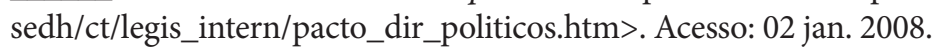


SOUZA LIMA, Antônio Carlos. Sobre gestar e gerir a desigualdade: pontos de investigação e diálogo. In: SOUZA LIMA, Antônio Carlos (Org.). Gestar e gerir: estudos para uma antropologia da administração pública no Brasil. Rio de Janeiro: Relume Dumará, 2002.

Um grande cerco de paz: poder tutelar, indianidade e formação do Estado no Brasil. Rio de Janeiro: Petrópolis, 1995.

VIEIRA, Jaci. Missionários, fazendeiros e índios em Roraima: a disputa pela terra 1777 a 1980. Dissertação (Mestrado)-UFPE. Recife, 2003.

WEBER, Max. Economia y sociedad. México: Fondo de Cultura Económica, 1983.

WEHLING, Arno; WEHLING, Maria José. Direito e justiça no Brasil colonial. Rio de Janeiro: Renovar, 2004.s 